\title{
Menentukan Distribusi Representatif \\ Frequensi Curahan Hujan Harian Maksimum Dengan Metodehistogram Dan Metode Parametik Di Provinsi Sumatera Barat
}

\author{
Selpa Dewi, ST.MT \\ Prodi Teknik Sipil \\ Universitas Muhammadiyah Sumatera Barat
}

\begin{abstract}
Abstact: The purpose of this research is to know the representative distribution in the province of South West Sumatera. The data used for this study were taken from the maximum daily rainfall data for 20 to 40 years, with 24 rain gauge stations for West Sumatera province. Each station's data is then arranged in two types of data series namely annual maxima data series and annual data series of exceedances. The results of this data series test are expected to follow one or more of the commonly used distributions in engineering hydrology, just like Normal distribution, normal-log, Gumbel, Gamma-II, Gamma-III and Log-Pearson Type III (LP-III) distributions. By using a goodness of fit test, parametric test, chi-square test, KolmogorofSmirnov test, Anderson Darling test and histogram method (visual).
\end{abstract}

Keywords : To determine the representative distribution by using annual maxima, annual exceendances, goodness of fit, in the provinces of West Sumatera.

Abstrak: Penelitian ini bertujuan untuk menentukan distribusi yang representatif frequensi curahan hujan harian maksimum di Provinsi Sumatera Barat. Data yang digunakan untuk penelitian ini diambil dari data hujan maksimum harian selama 20 sampai 40 tahunan, dengan 24 stasiun penakar hujan untuk provinsi Sumatera Barat. Data masing-masing stasiun kemudian disusun dalam dua jenis deret data, yaitu deret data annual maxima dan deret data annual exceedances. Dari hasil uji deret data ini diharapkan mengikuti satu atau beberapa dari distribusi yang umum dipakai dalam hidrologi rekayasa, yaitu distribusi normal, normal-log, Gumbel, Gama-II, Gama-III dan distribusi Log-Pearson Type III (LP-III). Dengan mengunakan uji kecocokan (goodness of fit), uji parametrik, Chi-Squared test, KolmogorovSmirnovtest dan Anderson-Darling test ditambah dengan metode histrogram (visual).

Kata kunci: Intensitas hujan distribusi representative annual maxima, annual exceendances, goodness of fitprovinsi Sumatera Barat.

\section{PENDAHULUAN}

Kota Padang merupkan Kota terbesar yang berada di pantai barat pulau Sumatera. Kota ini merupakan pintu gerbang barat Indonesia dari Samudera Hindia. Luas Kota Padang adalah 694, $96 \mathrm{~km}^{2}$ dengan kondisi geografis berbatasan dengan laut dan dikelilingi oleh perbukitan dengan ketinggian mencapai 1.853 mdpl. Padang memiliki garis pantai sepanjang 68,126 km di daratan Sumatera (Supriadi,2013) ${ }^{1}$.

Penelitian sekarang dilakukan di Padang. Penelitian ini mengenai data curahan hujan yang beragam melalui beberapa stasiun penakar hujan yang bertujuan untuk memilih dan menentukan jenis distribusi frekuensi yang tepat dan reperesentatif sehingga dapat ditentukan intensitas curah hujan rencana di daerah tersebut.

Harto (1993) ${ }^{2}$ menyatakan bahwa pemilihan jenis distribusi yang tidak sesuai dapat mengundang kesalahan yang cukup besar, baik 'over-estimated' maupun 'underestimated', keduanya tidak diinginkan. Harto (1993) juga menyatakan bahwa di Indonesia banyak dilakukan analisis frekuensi dengan menggunakan distribusi Gumbel tanpa pengujian data dan alasan hidrologik yang 
jelas. Dikhawatirkan cara ini dianggap sebagai cara yang sudah rutin, sehingga mengakibatkan risiko penyimpangan yang tidak dikehendaki.

Banyaknya jenis distribusi yang dipakai disebabkan oleh ketersediaan data hujan dan debit sungai yang relatif sedikit, terutama di Indonesia. Karena itulah dibutuhkan data hujan minimal 20 tahunan untuk dapat terbentuknya pendistribusian yang baik sehingga akan terbentuk secara mengerucut arah pendistribusiannya.

Sebelumnya sudah pernah ada penelitian mengenai masalah pemihan jenis distribusi ini di antaranya adalah Sutikno dan Bey $(2003)^{3}$, Machairiyah $(2007)^{4}$,Widyasari $(2009)^{5}$, Agus $(2010)^{6}$, Agus dan Hartati $(2011)^{7}$, Ruhiat $(2013)^{8}$, Rodrik dkk (2013) ${ }^{9}$ dan Sukmara (2014) ${ }^{10}$.

Ketertarikan penulis dalam penelitian kali ini disebabkan karena wilayah yang diteliti merupakan satu pulau yang sama akan tetapi memiliki posisi georafis yang berbeda. Dengan mengunakan data curahan hujan maksimum harian diambil selama minimal 20 tahunan diharapkan terdistribusi dengan baik. Uji kecocokan (goodness of fit test) yang dipakai yaitu metode histogram, uji parametrik, Chi-Squared test, Kolmogorov-Smirnov (K-S) test dan Anderson-Darling (A-D) test.

\section{METODE PENELITIAN}

Tujuan utama (primary objective) dari penelitian ini adalah menentukan jenis

\footnotetext{
Suktino, A. Bey, 2003, Analisis Peluang Untuk Memprediksi Kejadian Iklim Ekstrim "Studi Kasus: Distribusi Curah Hujan di Kabupaten Kerawang, Indramayu dan Subang "J Agromet,hal 62-72 http://journal.ipb.ac.id/index.php/agromet/article/view/3592 (diakses pada tangga
16 juni 2015) ${ }_{4}^{16}$ juni 2015) Machairiyah, 2007, Analisis Curah Hujan Untuk Pendugaan Debit Puncak Dengan Metode Rasional Pada DAS Percut Kabupaten Deli Serdang, USU, Medan http://www.researchgate.net/publication/42349045. (diakses pd tanggal 16 juni 2015 )

${ }_{5}^{\text {tanggal }} 16$ juni 2015) Persamaan Mononabe di Kabupaten Sleman, Janateknika hal 85 94.http://jurnalteknik.janabadra.ac.id/wp./Bu titik 09.pdf (diakses pada tanggal 18 juli 2015).

Smirnov Ko Agus,l., 2010, Penentuan Jenis Distribusi dan Uji Kesesuaian

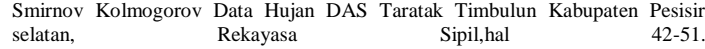
http://ojs.polinpdg.ac.id/index.php/JRS/article/view/221 (diakses pada tanggal 18 juli 2015).

7 Agus, I., Hartati, 2011, Uji kesesuaian Chi Kuadrat Data Hujan DAS Batang Kuranji Kota Padang, Rekayasa Sipil,hal 99-111. http://journal polinpdg.ac.id/index.php/article jd.240 (diakses pada tanggal 20 juli 2015)

Ruhiat, Y., 2013 Distribusi Curah Hujan harian dengan Uji ChiSquare.Kolmogorov-Smirnov, dan Anderson-Darling (studi kasus: Distribusi Curah Hujan Stasiun Serang), Prosiding Seminar Nasional Matematika dan Pendidikan Matematika 2013, Unand, Padang hal 133-139.

Rodrik,T,.K.S.Lubis,2013,Kajian Distribusi Curah Hujan Pada Beberapa Stasiun Penangkar Curah Hujan di DAS Padang, Jurnal Online Agroekoteknologihttp://journal Cusuac.id

lindex php/agroekoteknogi/aticle/view/5838 (diakes pada tanggl 16 juni 2015) ${ }_{10}$ index.php/agroekoteknolo 16 juni 2015) $\underline{\text { di Sumatera Barat dan di Jawa Tengah.tesis Universitas Andalas, Padang 72p. }}$
}

$74 \quad$ Fakultas Teknik UMSB

ISSN 2599-2081

EISSN 2599-2090 hujan yang ada di Provinsi Sumatera Barat. Untuk itu, tujuan khusus (secondary

$a$ Menyusun deret data curahan hujan maksimum harian di Sumatera Barat dengan annual maximum series dan annual exceedance series.

$b$ Menentukan distribusi data curahan hujan maksimum harian di Provinsi Sumatera Barat secara visual dengan cara membuat histogram.

c Menentukan distribusi dengan uji Histogram dan uji parametrik yaitu mencocokkan koefisien kecondongan dari distribusi normal, distribusi normal-log, distribusi Gumbel, dan distribusi LP-III dengan koefisien kecondongan yang diperoleh dari deret data curahan hujan yang ada di Sumatera Barat.

\section{Manfaat}

Penelitian ini diharapkan dapat melahirkan distribusi yang representatif untukwilayah Sumatera Barat.

\section{Batasan}

Pembahasan dari penelitian ini dibatasi oleh:

a Wilayah yang diteliti adalah wilayah Sumatera Barat

$b$ Peta Topografi dan peta lokasi stasiun hujan di Provinsi Sumatera Barat.

Gambar 1. Peta Topografi Prov.Sumbar objectives) dari penelitian ini adalah: distribusi gama-II, distribusi gama-III

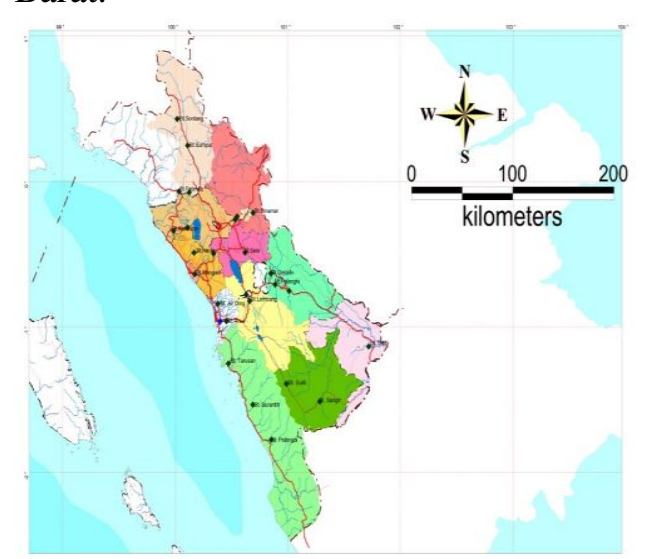


Tabel 1. Nama stasiun penakar hujan

Provinsi Sumatera Barat

\begin{tabular}{|c|c|c|c|c|c|c|c|c|}
\hline No & Nama Stasiun & $\begin{array}{l}\text { Panjang } \\
\text { Data }\end{array}$ & $\begin{array}{l}\text { Jumlah } \\
\text { Data }\end{array}$ & Tipe Alat & Nama Pemilik & Desa & Kecamatan & Kota /Kabupaten \\
\hline 1 & 50 Kota Tanjung Pati & 19862006 & 20 & Manual & Balai PSDA Wil Sungai Dareh & 50 Kota & Tj.Pati & 50 Koto \\
\hline 2 & 50 Kota Suliki & 19852012 & 27 & Manual & Balai PSDA Wil Sungai Dareh & Suliki & Suliki & 50 Koto \\
\hline 3 & Batu Busuk & 19752013 & 38 & RG / ARR & Balai PSDA Wil Sungai Dareh & Batu Busuk & Pauh & Padang \\
\hline 4 & Koto Tuo & 19732013 & 40 & Manual & Balai PSDA Wil Sungai Dareh & Koto Tuo & Koto Tanggah & Padang \\
\hline 5 & Simpang Alai & 19752014 & 39 & RG / ARR & Balai PSDA Wil Sungai Dareh & Simp.Alai & Pauh & Padang \\
\hline 6 & Danau Diatas & 19822013 & 31 & Manual & Balai PSDA Wil Sungai Dareh & Danau Diatas & Danau Diatas & Solok \\
\hline 7 & Pasel Surantih & 19822012 & 30 & $\mathrm{RG}$ & Balai PSDA Wil Sungai Dareh & Surantih & Sutera Pasel & Pasaman Selatan \\
\hline 8 & Pasel Tarusan & 19782014 & 36 & Manual & Balai PSDA Wil Sungai Dareh & Tarusan & KotoXI Tarusan & Pasaman Selatan \\
\hline 9 & Sijunjung & 19812012 & 31 & Manual & Balai PSDA Wil Sungai Dareh & Btg.Sukam & Sijunjung & S.L Sijunjung \\
\hline 10 & Solok Sumani & 19852015 & 30 & RG / ARR & Balai PSDA Wil Sungai Dareh & Sumani & Sumani & Solok \\
\hline 11 & Pasaman Barat ujung Gading & 19832013 & 30 & Manual & Balai PSDA Wil Sungai Dareh & Ujung Gading & Ujung Gading & Pasaman Barat \\
\hline 12 & Pdg. Pariaman Kadang IV & 19802012 & 32 & RG / ARR & Balai PSDA Wil Sungai Dareh & Kandang IV & Enam Lingkung & P.Pariaman \\
\hline 13 & Solok Air Santok & 19792012 & 33 & Manual & Balai PSDA Wil Sungai Dareh & Santok & Solok Air & Solok \\
\hline 14 & Pdg pariaman Lubuk Napar & 19792011 & 32 & RG / ARR & Balai PSDA Wil Sungai Dareh & Lubuk Napar & Kayu Tanam & P.Pariaman \\
\hline 15 & Mangopoh & 19842011 & 27 & $\mathrm{RG}$ & Balai PSDA Wil Sungai Dareh & Mangopoh & Lb.Basung & Agam \\
\hline 16 & Maninjau Agam & 19832013 & 30 & $\mathrm{RG}$ & Balai PSDA Wil Sungai Dareh & Maninjau & Maninjau & Agam \\
\hline 17 & Agam Gumarang & 19832011 & 28 & Manual & Balai PSDA Wil Sungai Dareh & Palembayan & Gumarang & Agam \\
\hline 18 & Padang Panjang & 19782013 & 35 & RG / ARR & Balai PSDA Wil Sungai Dareh & Btg Anai & P.Panjang & P.Panjang \\
\hline 19 & Pdg Pariaman Kasang & 19802010 & 30 & Manual & Balai PSDA Wil Sungai Dareh & Kasang & Btg.Anai & P.Pariaman \\
\hline 20 & Pariaman Talang & 19822014 & 32 & Manual & Balai PSDA Wil Sungai Dareh & Btg Manggau & Tandikek & P.Pariaman \\
\hline 21 & Sungai Ipuh & 19792014 & 35 & $\mathrm{RG}$ & Balai PSDA Wil Sungai Dareh & Sungai Ipuh & Kp.Gadang & Solok Selatan \\
\hline 22 & Tanah datar buo & 19832012 & 29 & RG / ARR & Balai PSDA Wil Sungai Dareh & Buo & Tanah datar & Tanah Datar \\
\hline 23 & Solsel Muaro Labuh & 19742014 & 40 & Manual & Balai PSDA Wil Sungai Dareh & Sako & Sungai Panguh & Solok Selatan \\
\hline 24 & Pdg Gunung Nago & 19792013 & 34 & Manual & Balai PSDA Wil Sungai Dareh & Pauh & Gunung Nago & Padang \\
\hline
\end{tabular}

C. Data yang diambil adalah data curahan hujan maksimum harian selama 20 tahunan sampai 40 tahunan dari tahun 1973 sampai dengan 2014 di Provinsi Sumatera Barat yang didapat dari Dinas PSDA Provinsi Sumatera Barat sebanyak 24 (dua puluh empat) stasiun seperti pada Tabel 1.1berdasarkan ketersediaan data yang ada.Prosedur dari penelitian yang penulis lakukan adalah sebagai berikut: 

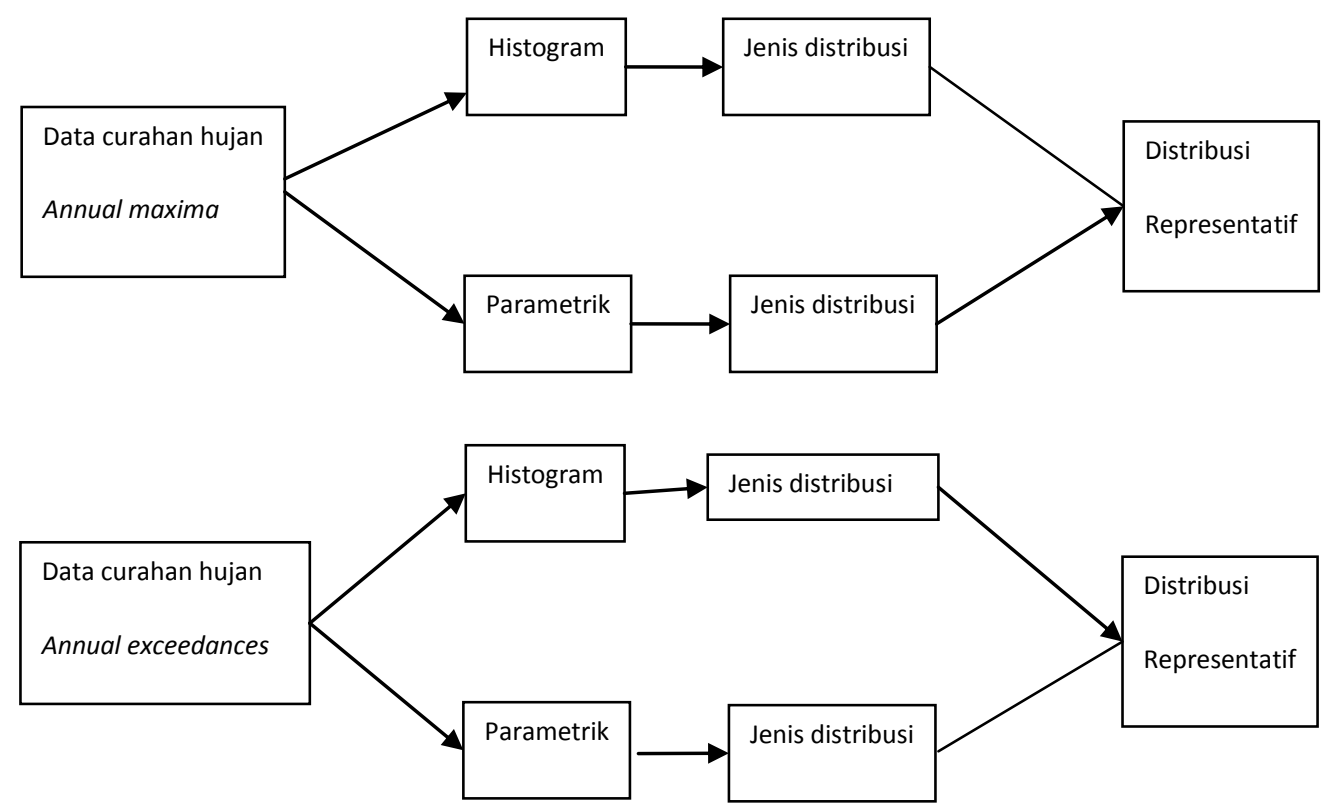

\section{HASIL DAN PEMBAHASAN} PENYUSUNAN DERET DATA

Dalam menyusun deret data untuk menentukan distribusi representatif pada curahan hujan rencana di Provinsi Sumatera Selatan dan Sumatera Barat dengan mengunakan data curahan hujan maksimum maka data disusun dalam dua jenis deret data yaitu deret data maksimum tahunan (series of annual maxima)dan deret data lebih besar tahunan (series of annual exceedances). Deret maksimum tahunan (series of annual maxima) adalah deret data yang diperoleh dari kumpulan data yang nilai maksimum setiap tahunnya, dimana setiap tahun diambil satu data yang mempunyai nilai maksimum. Sedangkan deret data lebih besar tahunan (series of annual exceedances)yaitu deret data yang diperoleh dari kumpulan sejumlah $n$ data yang mempunyai nilai $n$ besar dari $n$ tahun. Seri kedua ini memasukkan data yang mempunyai nilai besar kedua, ketiga dan seterusnya pada tahun tertentu yang lebih besar dari data yang mempunyai nilai besar kesatu pada tahun yang lain. Dengan kata lain, seri data kedua ini bisa saja mengambil lebih dari satu data pada tahun tertentu dan tidak mengambil pada tahun lain (Mera, 2011) ${ }^{1}$

Tabel .2 Deret data tiga besar dari data Stasiun Koto Tuo

\begin{tabular}{rrrrr}
\hline \multirow{2}{*}{ No. } & \multirow{2}{*}{ Tahun } & \multicolumn{3}{c}{ Debit Tiga Besar $\left(\mathbf{m}^{3} / \mathbf{s}\right)$} \\
\cline { 3 - 5 } & & ke-1 & ke-2 & ke-3 \\
\hline 1 & 1974 & 100 & 98 & 93 \\
\hline 2 & 1975 & 100 & 96 & 90 \\
\hline 3 & 1976 & 195 & 185 & 178 \\
\hline 4 & 1977 & 120 & 119 & 115 \\
\hline 5 & 1978 & 185 & 176 & 170 \\
\hline 6 & 1979 & 192 & 182 & 180 \\
\hline 7 & 1980 & 253 & 238 & 233 \\
\hline 8 & 1981 & 315 & 312 & 280 \\
\hline 9 & 1982 & 265 & 255 & 250 \\
\hline 10 & 1983 & 182 & 175 & 169 \\
\hline 11 & 1984 & 193 & 187 & 180 \\
\hline 12 & 1985 & 155 & 153 & 150 \\
\hline 13 & 1986 & 218 & 212 & 210 \\
\hline 14 & 1987 & 216 & 198 & 190 \\
\hline 15 & 1988 & 127 & 116 & 112 \\
\hline 16 & 1989 & 121 & 111 & 108 \\
\hline 17 & 1990 & 106 & 96 & 92 \\
\hline 18 & 1991 & 155 & 135 & 133 \\
\hline 19 & 1992 & 149 & 140 & 137 \\
\hline 20 & 1993 & 113 & 100 & 99 \\
\hline & & & &
\end{tabular}

\begin{tabular}{rrrrr}
\hline \multirow{2}{*}{ No. } & \multirow{2}{*}{ Tahun } & \multicolumn{3}{c}{ Debit Tiga Besar $\left(\mathbf{m}^{3} / \mathrm{s}\right)$} \\
\cline { 3 - 5 } & & \multicolumn{1}{c}{ ke-1 } & ke-2 & ke-3 \\
\hline 21 & 1994 & 143 & 123 & 110 \\
\hline 22 & 1995 & 195 & 188 & 178 \\
\hline 23 & 1996 & 196 & 191 & 190 \\
\hline 24 & 1997 & 98 & 83 & 72 \\
\hline 25 & 1998 & 260 & 242 & 222 \\
\hline 26 & 1999 & 194 & 189 & 188 \\
\hline 27 & 2000 & 242 & 200 & 199 \\
\hline 28 & 2001 & 204 & 201 & 198 \\
\hline 29 & 2002 & 290 & 278 & 265 \\
\hline 30 & 2003 & 223 & 205 & 198 \\
\hline 31 & 2004 & 207 & 199 & 197 \\
\hline 32 & 2005 & 498 & 343 & 234 \\
\hline 33 & 2006 & 500 & 476 & 378 \\
\hline 34 & 2007 & 114 & 84 & 53 \\
\hline 35 & 2008 & 89 & 76 & 63 \\
\hline 36 & 2009 & 82 & 78 & 43 \\
\hline 37 & 2010 & 215 & 199 & 187 \\
\hline 38 & 2011 & 155 & 134 & 125 \\
\hline 39 & 2012 & 152 & 122 & 109 \\
\hline 40 & 2013 & 174 & 170 & 167 \\
\hline & & & &
\end{tabular}


Vol. I No.1 Januari 2018

http://joernal.umsb.ac.id/index.php/RANGTEKNIKJOURNAL

Tabel 3 Tabel data annual maxima dan annual excedeces stasiun Koto Tuo

\begin{tabular}{ccc}
\hline & \multicolumn{2}{c}{ Debit $\left(\mathbf{m}^{3} / \mathbf{s}\right)$} \\
\cline { 2 - 3 } No. & $\begin{array}{c}\text { Annual } \\
\text { Maxima }\end{array}$ & $\begin{array}{c}\text { Annual } \\
\text { Exceedances }\end{array}$ \\
\hline 1 & 231,03 & 221,02 \\
\hline 2 & 194,53 & 187,80 \\
\hline 3 & 178,35 & 170,20 \\
\hline 4 & 170,00 & 167,00 \\
\hline 5 & 169,00 & 159,00 \\
\hline 6 & 166,00 & 136,00 \\
\hline 7 & 164,00 & 101,30 \\
\hline 8 & 159,00 & 95,03 \\
\hline 9 & 156,00 & 84,35 \\
\hline 10 & 150,00 & 83,48 \\
\hline 11 & 149,00 & 82,33 \\
\hline 12 & 147,00 & 81,00 \\
\hline 13 & 143,00 & 79,88 \\
\hline 14 & 140,00 & 78,40 \\
\hline 15 & 138,00 & 76,20 \\
\hline 16 & 127,00 & 74,00 \\
\hline 17 & 122,00 & 70,00 \\
\hline 18 & 121,00 & 69,00 \\
\hline 19 & 119,00 & 67,00 \\
\hline 20 & 101,00 & 66,00 \\
\hline & &
\end{tabular}

\begin{tabular}{ccc}
\hline No. & \multicolumn{2}{c}{ Debit $\left(\mathrm{m}^{3} / \mathrm{s}\right)$} \\
\cline { 2 - 3 } & $\begin{array}{c}\text { Annual } \\
\text { Maxima }\end{array}$ & $\begin{array}{c}\text { Annual } \\
\text { Exceedances }\end{array}$ \\
\hline 21 & $\mathbf{9 8 , 0 0}$ & 59,00 \\
\hline 22 & $\mathbf{8 8 , 0 0}$ & 57,00 \\
\hline 23 & 76,00 & 55,00 \\
\hline 24 & 66,00 & 51,00 \\
\hline 25 & 63,00 & 49,00 \\
\hline 26 & 58,00 & 47,00 \\
\hline 27 & 52,00 & 45,00 \\
\hline 28 & 48,00 & 43,00 \\
\hline 29 & 45,00 & 38,00 \\
\hline 30 & 30,00 & 36,00 \\
\hline 31 & 29,00 & 35,00 \\
\hline 32 & 28,00 & 30,00 \\
\hline 33 & 23,00 & 29,00 \\
\hline 34 & 19,00 & 27,00 \\
\hline 35 & 18,00 & 25,00 \\
\hline 36 & 15,00 & 24,00 \\
\hline 37 & 14,00 & 23,00 \\
\hline 38 & 12,00 & 20,00 \\
\hline 39 & 10,00 & 18,00 \\
\hline 40 & 9,80 & 15,00 \\
\hline & &
\end{tabular}

\section{UJI KECOCOKAN DERET DATA DENGAN HISTOGRAM}

Pembuatan histogram banyak dilakukan orang sebagai asumsi awal untuk menentukan jenis distribusi terhadap data yang diteliti. Mera (2011) menyatakan bahwa tinggi dan bentuk umum histogram berguna untuk melihat karakteristik data seperti apakah data tersebut simetris atau condong (miring, menceng, tidak normal,skewed). Data dianggap terdistribusi secara normal jika histogram yang terbentuk oleh data tersebut simetris. Sedangkan data dianggap tidak terdistribusi secara normal jika histogram yang terbentuk oleh data tersebut condong seperti yang ditunjukkan pada Gambar berikut ini :
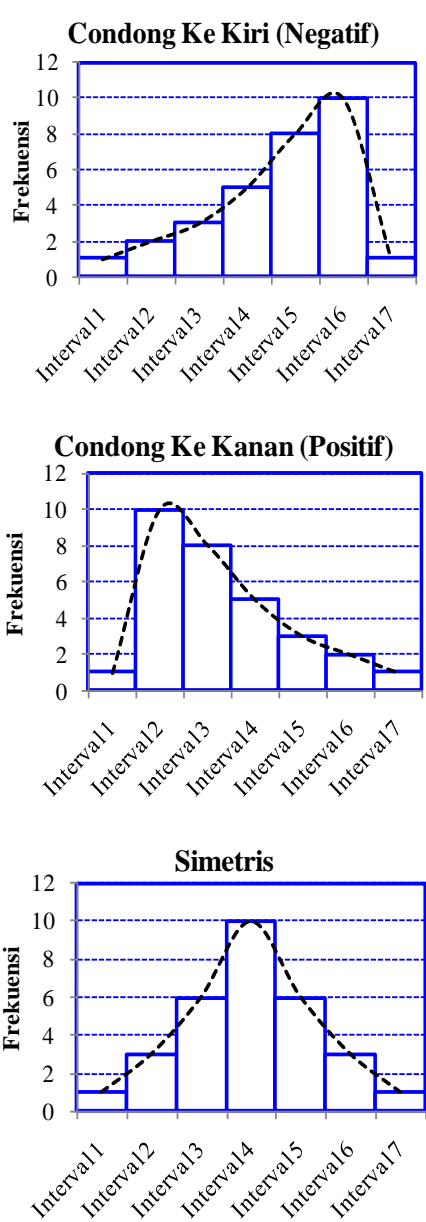

Gambar 2Histogram 


\section{Vol. I No.1 Januari 2018 \\ http://joernal.umsb.ac.id/index.php/RANGTEKNIKJOURNAL

Pembuatan histogram dilakukan dengan membagi deret data yang terdiri dari $n$ data dalam $l$ interval kelas. Menurut Mera $(2011)^{11}$ berdasarkan pendapat Bedient dan Huber (1992) $)^{12}$, jumlah interval kelas dapat dihitung menggunakan persamaan:

$$
l=5 \log _{10} n
$$

Penulis akan menjelaskan prosedur pembuatan histogram untuk deret data debit annual maxima dan annual exceedances stasiun Koto Tuo, dimana $n=40$ yaitu:

a Mengurut data dari yang terbesar ke yang terkecil atau yang terkecil ke yang terbesar;

$b \quad$ Menentukan jumlah interval kelas menggunakan persamaan rumus.1 seperti yang ditunjukkan pada Tabel berikut ini:

Tabel 4 Interval kelas deret data stasiun Koto Tuo
Tabel.5 Interval kelas deret data dari stasiun Koto Tuo

\begin{tabular}{|c|c|c|c|c|c|}
\hline \multirow{2}{*}{ No. } & \multirow{2}{*}{\multicolumn{3}{|c|}{ Kelas Interval }} & \multicolumn{2}{|c|}{ Batas Kelas } \\
\hline & & & & bawah & atas \\
\hline 1 & 1.9100 & - & 1.9900 & 1.9050 & 1.9950 \\
\hline 2 & 2.0000 & - & (rumus & 1.9950 & 2.0850 \\
\hline 3 & 2.0900 & - & 2.1700 & 2.0850 & 2.1750 \\
\hline 4 & 2.1800 & - & 2.2600 & 2.1750 & 2.2650 \\
\hline 5 & 2.2700 & - & 2.3500 & 2.2650 & 2.3550 \\
\hline 6 & 2.3600 & - & 2.4400 & 2.3550 & 2.4450 \\
\hline 7 & 2.4500 & - & 2.5300 & 2.4450 & 2.5350 \\
\hline 8 & 2.5400 & - & 2.6200 & 2.5350 & 2.6250 \\
\hline \multirow[t]{2}{*}{9} & 2.6300 & - & 2.7100 & 2.6250 & 2.7150 \\
\hline & \multicolumn{3}{|c|}{ Jumlah } & & \\
\hline
\end{tabular}

$d \quad$ Menentukan ujung bawah interval kelas pertama $a_{1}$, lebar interval kelas $p$ dan ujung atas interval kelas terakhir $b_{l}$. Ujung bawah kelas bisa diambil sama dengan data terkecil atau

\begin{tabular}{rlr}
\hline Deret Data & $n$ & terakhirb $b_{l}$ Ujung bawah kelas bisa \\
diambilsama dengan data terkecil atau \\
\hline Annual maxima & 40 & $8.01_{\text {nifraitauta kylats lebih kecil dari data }}$
\end{tabular}

Annual exceedances $\quad 40 \quad 8.01$ terkatal tekapasselisihnya dengan data

$c \quad$ Menentukan ujung bawah interval kelas pertama $a_{1}$, lebar interval kelas $p$ dan ujung atas interval kelas terakhir $b_{l}$. Ujung bawah kelas bisa diambil sama dengan data terkecil atau nilai data yang lebih kecil dari data terkecil tetapi selisihnya dengan data terkecil harus kurang dari lebar interval kelas (Sudjana, 2005) ${ }^{13}$. Sedangkan interval kelas dan ujung atas interval kelas terakhir dapat dihitung dengan persamaan:

$p=\frac{x_{\max }-a_{1}}{l}$

$b_{l}=p \times l+a_{1}-1$

Dimana:

$\begin{array}{lll}p & = & \text { lebar interval kelas } \\ x_{\max } & = & \text { data maksimum }\end{array}$

$a_{1} \quad=$ ujung bawah

interval kelas pertama

$b_{1} \quad=\quad$ ujung atas interval

kelas terakhir terkecil harus kurang dari lebar interval kelas (Sudjana, 2005) ${ }^{14}$. Sedangkan interval kelas dan ujung atas interval kelas terakhir dapat dihitung dengan persamaan: $p=\frac{x_{\max }-a_{1}}{l}$

$e \quad$ Menentukan ujung bawah interval kelas ke- $i$ pada setiap interval kelas dengan persamaan:

$a_{i}=a_{i-1}+p$

dimana $a_{i}=$ ujung bawah interval kelas ke- $i$ (rumus 2)

$f \quad$ Menentukan ujung atas interval kelas ke- $i$ pada setiap intermathkslas dengan persamaan:

$b_{i}=a_{i+1}-1$

dimana $b_{i}=$ ujung atasinterval kelas ke- $i$ Menentukan batas bawah $x_{a}$ dan batas atas $x_{b}$ pada interval kelas yang sama.Jika ujung bawah dan ujung atas dicatat hingga satuan, maka batas bawah diperoleh dari ujung bawah dikurangisetengah dari satu satuan dan

\footnotetext{
${ }^{1}$ Mera, M., 2011, Hidrologi Rekayasa, CV. Ferila Padang, 179p

${ }_{22}$ Bedient, P. B. dan Huber W. C. 1992, Hydrology and Floodplain Analysis, Addison-Wesley Publishing Company, 712p.

${ }^{13}$ Sudjana, 2005, Metoda Statistika, Tarsito, Bandung, 508p

${ }^{14}$ Sudjana, 2005, Metoda Statistika, Tarsito, Bandung, 508p
} 
batas atas diperoleh dari ujung atas ditambah setengah dari satu satuan. Jika ujung bawah dan ujung atas dicatat hingga satu desimal, maka batas bawah diperoleh dari ujung bawah dikurang setengah dari satu desimal dan batas atas diperoleh dari ujung atas ditambah setengah dari satu desimal. Nilai batas atas ke- $i$ akan sama dengan nilai batas bawah ke$i+1$.

$h \quad$ Menentukan frekuensi $f$ deret data debit annual maxima dan annual exceedancesstasiun Koto Tuo berdasarkan pembagian kelasnya. Gambar a merupakan ilustrasi proses penentuan frekuensi deret data debit annual maxima dan annual exceedances stasiun Koto Tuo

Menggambarkan bentuk histogram deret data debit annual maxima dan annualexceedances stasiun Koto Tuo yang ditunjukkan pada Gambar berikut ini:

\section{Histogram Annual Maxima}

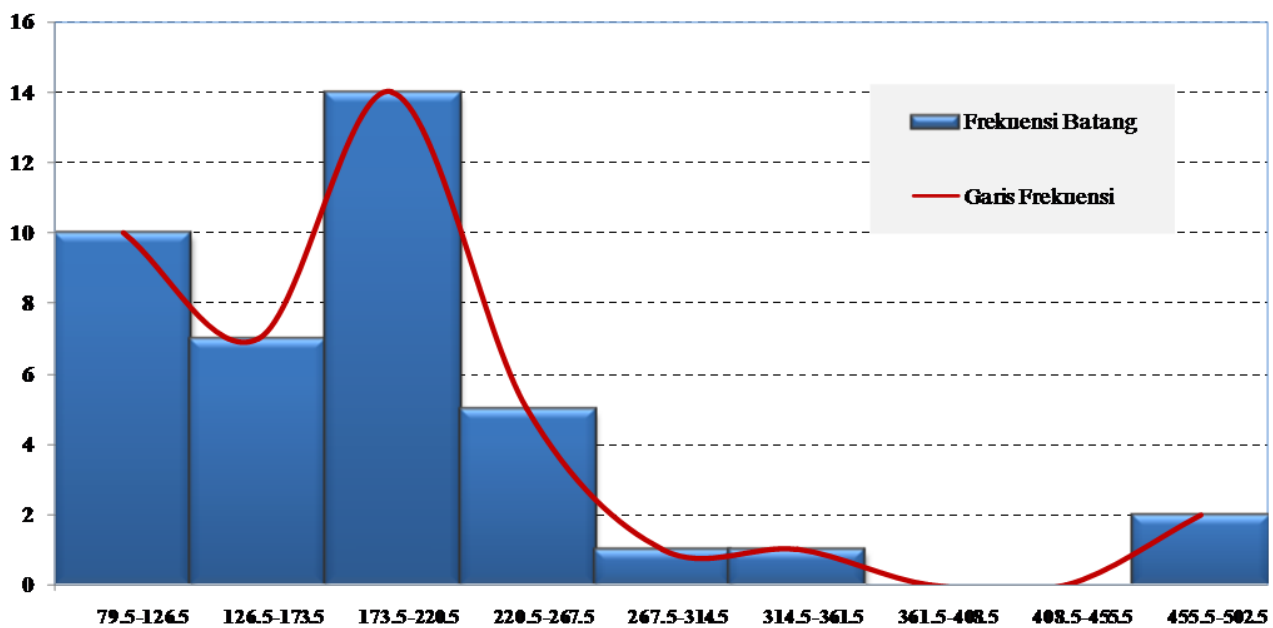

Gambar.3 Bentuk histogram deret data hujanannual maxima stasiun Koto Tuo

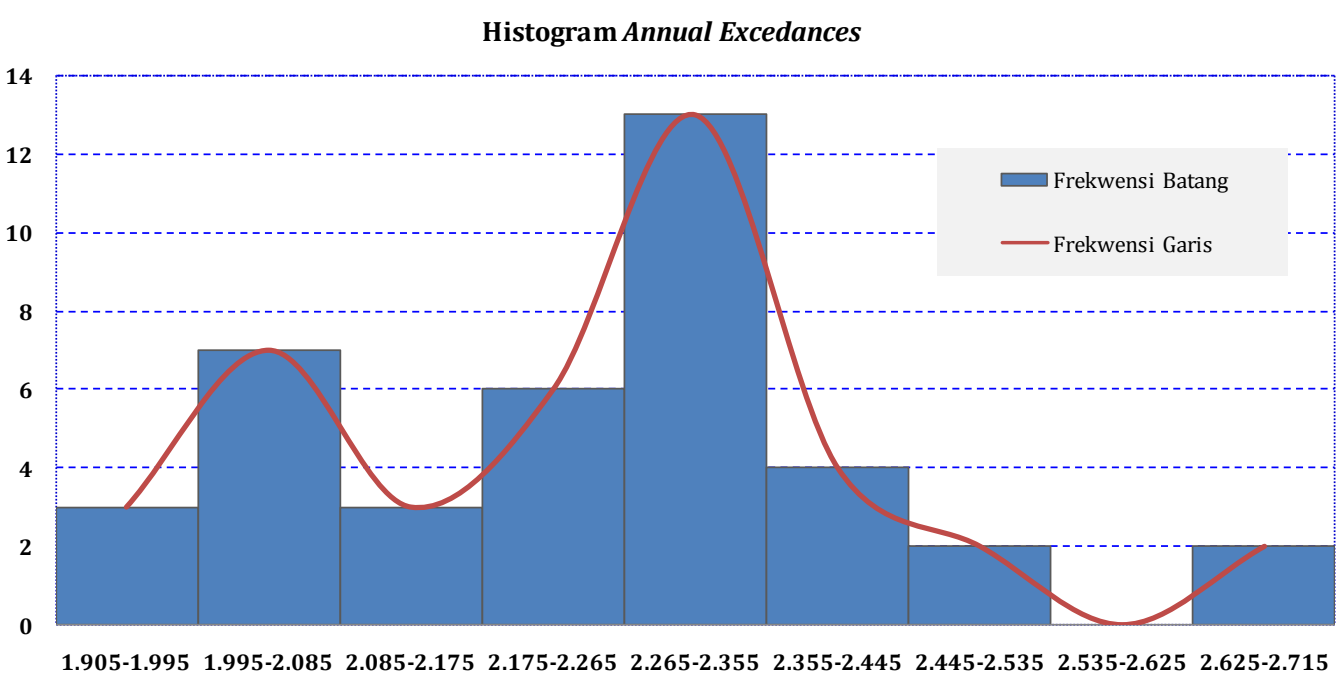

Gambar4 Bentuk histogram deret data hujanannual Excedences stasiun Koto Tuo 
Secara visual terlihat bahwa pola dari histogram untuk deret data annual maxima dan annual exceedances stasiun Koto Tuo condong ke kanan. Itu artinya data tidak terdistribusi secara normal atau data akan mengikuti salah satu dari distribusi Normal-log, Gumbel, gama II, gama III dan distribusi LP-III.

Tabel ini merupakan bentuk histogram pada masing-masing stasiun di Provinsi Sumatera Barat.

Tabel.6. Hasil uji Histogram Di Provinsi Sumatera Barat

\begin{tabular}{|c|c|c|c|c|c|}
\hline \multirow{2}{*}{ No. } & \multirow{2}{*}{ Nama Stasiun } & \multirow{2}{*}{$\begin{array}{r}\text { Panjang } \\
\text { Data }\end{array}$} & \multirow{2}{*}{$\begin{array}{r}\text { Dari } \\
\text { Tahun }\end{array}$} & \multicolumn{2}{|c|}{ Bentuk Histogram } \\
\hline & & & & Annual Maxima & Annual Exceedances \\
\hline 1 & Sungai ipuh & 35 & 1977- 2011 & Condong ke kanan & Condong ke kanan \\
\hline 2 & Tanah datar Buo & 31 & $1983-2013$ & Condong ke kanan & Condong ke kanan \\
\hline 3 & 50 Koto tj Pati & 34 & 1979-2012 & Condong ke kanan & Simetris \\
\hline 4 & 50 Koto Suliki & 30 & 1981 - 2011 & Condong ke kanan & Condong ke kanan \\
\hline 5 & Agam Gumarang & 28 & $1985-2012$ & Condong ke kanan & Condong ke kanan \\
\hline 6 & Agam Maninjau & 30 & 1980-2009 & Condong ke kanan & Condong ke kanan \\
\hline 7 & Batu Busuk & 38 & $1975-2012$ & Condong ke kanan & Condong ke kanan \\
\hline 8 & Koto Tuo & 40 & 1974-2013 & Condong ke kanan & Condong ke kanan \\
\hline 9 & Mangopoh & 27 & 1981 - 2011 & Simetris & Condong ke kanan \\
\hline 10 & Padang Panjang & 35 & 1977-2011 & Condong ke kanan & Condong ke kanan \\
\hline 11 & Pariaman Kandang IV & 32 & 1981 - 2012 & Condong ke kanan & Condong ke kanan \\
\hline 12 & Pariaman Lubuk Napar & 32 & 1978-2009 & Condong ke kanan & Condong ke kanan \\
\hline 13 & Pariaman Kasang btg anai & 30 & $1979-2008$ & Condong ke kanan & Condong ke kanan \\
\hline 14 & Solok Air Santok & 23 & 1978-2010 & Condong ke kanan & Condong ke kanan \\
\hline 15 & Simpang Alai & 39 & $1975-2013$ & Condong ke kanan & Simetris \\
\hline 16 & Danau diatas & 31 & $1980-2010$ & Condong ke kanan & Condong ke kanan \\
\hline 17 & Pasel Surantih & 30 & 1984-2013 & Condong ke kanan & Condong ke kanan \\
\hline 18 & Pasel Tarusan & 36 & 1978-2013 & Condong ke kanan & Condong ke kanan \\
\hline 19 & Sijunjung & 31 & $1982-2012$ & Condong ke kanan & Condong ke kanan \\
\hline 20 & Solok Sumani & 30 & 1980-2009 & Simetris & Simetris \\
\hline 21 & Muaro labuh & 40 & 1974-2013 & Condong ke kanan & Condong ke kanan \\
\hline 22 & Padang Gunung Nago & 34 & $1980-2013$ & Condong ke kanan & Condong ke kanan \\
\hline 23 & Pdg Pariaman Talang & 32 & $1980-2011$ & Simetris & Condong ke kanan \\
\hline 24 & Pasbar Ujung gading & 30 & $1981-2010$ & Condong ke kanan & Condong ke kanan \\
\hline $\begin{array}{l}\text { paran } \\
\text { statis } \\
\text { deng } \\
\text { dari } \\
\text { yang }\end{array}$ & $\begin{array}{l}\text { ECOCOKAN DERET } \\
\text { AN UJI PARAMETR } \\
\text { Penentuan distribusi } \\
\text { trik adalah menghi } \\
\mathrm{k} \text { dari data dan } \mathrm{n} \\
\text { ciri-ciri statistik yc } \\
\text { nasing-masing distril } \\
\text { iuji adalah distribusi } \mathrm{N}\end{array}$ & $\begin{array}{l}\text { DATA } \\
\text { IK } \\
\text { eerdasark } \\
\text { ung par } \\
\text { encocok } \\
\text { ng disy } \\
\text { usi. Di } \\
\text { ormal, N }\end{array}$ & $\begin{array}{l}\text { n uji } \\
\text { meter } \\
\text { annya } \\
\text { atkan } \\
\text { ribusi } \\
\text { rmal- }\end{array}$ & \multicolumn{2}{|c|}{$\begin{array}{l}\text { Log, distribusi Gumbel, gama-II, gama-III } \\
\text { dan distribusi LP-III. Karena pada umumnya } \\
\text { data yang dipakai untuk analisis frekuensi } \\
\text { dibidang hidrologi rekayasa relatif sedikit, } \\
\text { maka koefisien kecondonganlah yang paling } \\
\text { prioritas. Tabel a merupakan parameter } \\
\text { statistik yang disyaratkan dalam uji } \\
\text { parametri }\end{array}$} \\
\hline
\end{tabular}


Tabel 7 Parameter Statistik yang disyaratkan oleh beberapa distribusi(Mera, 2011; Bedient dan Huber, 1992)

\begin{tabular}{rll}
\hline No. & Jenis Distribusi & Koefisien Kecondongan \\
\hline 1 & Normal & $C_{s}=0$ \\
\hline 2 & Normal-log & $C_{s}=C_{v}{ }^{3}+3 C_{v}$ \\
\hline 3 & Gumbel & $C_{s}=1.14$ \\
\hline 4 & Gama-II & $C_{s}=2 C_{v}{ }^{2}$ \\
\hline 5 & Gama-III & Selain syarat pada no. 1 s.d. 4 \\
\hline 6 & Log-Pearson-III & Selain syarat pada no. 1 s.d. 4 \\
\hline
\end{tabular}

Menurut Mera (2011), persamaan dimana : untuk menghitung parameter statistik $\bar{x}=$ nilai rata-rata didefinisikan sebagai berikut:

$$
\begin{aligned}
& \bar{x}=\frac{1}{n} \sum_{i=1}^{n} x_{i} \\
& S=\sqrt{\frac{1}{n-1} \sum_{i=1}^{n}\left(x_{i}-\bar{x}\right)^{2}} \\
& C_{s}=\frac{n}{(n-1)(n-2)} \frac{\sum\left(x_{i}-\bar{x}\right)^{3}}{S^{3}} \\
& C_{v}=\frac{S}{\bar{x}}
\end{aligned}
$$

$$
x_{i}=\quad \text { data ke- } i
$$

$i=$

$2,3, \ldots, n_{\text {rumus.6) }}^{n}$

$S=\quad$ deviasi standar

$C_{s} \quad=\quad$ koefisien

kecondongan

(rumus 7)

Tabel $\mathrm{b}$ merupakan nilai parameter statistik

\begin{tabular}{|c|c|c|}
\hline Parameter & Annual Maxima & Annual Exceedances \\
\hline Rata-rata & 192,28 & 208,22 \\
\hline Deviasi standar & 91,38 & 75,43 \\
\hline Koefisien kecondongan & 7,09 & 8,19 \\
\hline Koefisien varians & 0,48 & 0,75 \\
\hline
\end{tabular}
dari deret data annual maxima dan annual exceedances stasiun KotoTuo.

(rumus.9)

Tabel 8 Nilai parameter statistik deret data stasiun Koto Tuo

untuk deret data annual maxima dan annual kecondongan yang disyaratkan dengan exceedances stasiun Koto Tuo yaitu:

a Menghitung parameter statistik dari koefisien kecondongan deret data deret data debit annual maxima dan annual exceedances stasiun Koto Tuo menggunakan persamaan .6 hingga persamaan 9 .

$b$ Menentukan koefisien kecondongan yang diisyaratkan untuk distribusi Normal, Normal-log, Gumbel, gamadebit annual maxima dan annual exceedances dari masing-masing distribusi. Tabel a merupakan perbandingan koefisienkecondongan yang disyaratkan dengan koefisien kecondongan hasil hitungan dari deret data stasiun Koto Tuo terhadap II, gama-III dan distribusi LP-III masing-masing distribusi.

berdasarkan Tabel a 
http://joernal.umsb.ac.id/index.php/RANGTEKNIKJOURNAL

Tabel 9. Perbandingan koefisien kecondongan yang disyaratkan dengan koefisien kecondongan dari deret data stasiun Koto Tuo.

\begin{tabular}{rlrrl}
\hline No. & Distribusi & Syarat & Cs & Hasil \\
\hline 1 & Normal & $\mathbf{0 , 0 0}$ & $\mathbf{1 , 9 0}$ & tidak memenuhi \\
\hline 2 & Normal-log & $\mathbf{1 , 5 3}$ & $\mathbf{1 , 9 0}$ & tidak memenuhi \\
\hline 3 & Gumbel & 1,14 & 1,90 & tidak memenuhi \\
\hline 4 & Gamma-II & 0,45 & 1,90 & tidak memenuhi \\
\hline 5 & Gamma-III & - & 1,90 & memenuhi \\
\hline 6 & LP-III & - & 1,90 & memenuhi \\
\hline
\end{tabular}

Tabel. 10 Rekapitulasi jenisdistribusi deret data debit annual maxima dari Provinsi Sumatera Barat berdasarkan uji parametrik

\begin{tabular}{|c|c|c|c|c|c|c|c|c|c|c|}
\hline \multirow{2}{*}{ No } & \multirow{2}{*}{ Nama Stasiun } & \multirow{2}{*}{$\begin{array}{r}\text { Jumlah } \\
\text { Data }\end{array}$} & \multicolumn{6}{|c|}{$C_{\text {syarat }}$} & \multirow[b]{2}{*}{$C_{s}$} & \multirow{2}{*}{ Jenis Distribusi } \\
\hline & & & $\mathbf{N}$ & N-L & G & G-II & G-III & LP-III & & \\
\hline 1 & Sungai ipuh & 35 & $\mathbf{0}$ & 1,12 & 1,14 & 0,26 & & & 1,25 & Gumbel \\
\hline 2 & Tanah datar Buo & 31 & $\mathbf{0}$ & 0,64 & 1,14 & 0,09 & 1,84 & 1,84 & 1,84 & Gama-III dan LP-III \\
\hline 3 & 50 Koto tj Pati & 34 & $\mathbf{0}$ & 1,05 & 1,14 & 0,23 & 0,68 & 0,68 & 0,63 & Gama-III dan LP-III \\
\hline 4 & 50 Koto Suliki & 30 & $\mathbf{0}$ & 1,01 & 1,14 & $\mathbf{0 , 2 1}$ & 1,86 & 1,86 & 1,86 & Gama-III dan LP-III \\
\hline 5 & Agam Gumarang & 28 & $\mathbf{0}$ & 1,97 & 1,14 & 0,69 & 1,73 & 1,73 & 1,73 & Gama-III dan LP-III \\
\hline 6 & Agam Maninjau & 30 & $\mathbf{0}$ & 0,72 & 1,14 & 0,11 & 1,87 & 1,87 & 1,87 & Gama-III dan LP-III \\
\hline 7 & Batu Busuk & 38 & $\mathbf{0}$ & 1,33 & 1,14 & 0,35 & 0,77 & 0,77 & $\mathbf{0 , 7 7}$ & Gama-III dan L.P-III \\
\hline 8 & Koto Tuo & 40 & $\mathbf{0}$ & 0,81 & 1,14 & 0,14 & 0,53 & 0,53 & 0,53 & Gama-III dan LP-III \\
\hline 9 & Mangopoh & 27 & $\mathbf{0}$ & 1,53 & 1,14 & 0,45 & 3,27 & 3,27 & 3,27 & Gama-III dan LP-III \\
\hline 10 & Padang Panjang & 35 & $\mathbf{0}$ & 1,04 & 1,14 & 0,22 & & & 1,29 & Gumbel \\
\hline 11 & Pariaman Kandang IV & 32 & $\mathbf{0}$ & 0,64 & 1,14 & 0,09 & 1,60 & 1,60 & 1,60 & Gama-III dan LP-III \\
\hline 12 & Pariaman Lubuk Napar & 32 & $\mathbf{0}$ & 1,08 & 1,14 & 0,24 & 2,37 & 2,37 & 2,37 & Gama-III dan I.P-III \\
\hline 13 & Pariaman Kasang btg anai & 30 & $\mathbf{0}$ & 0,79 & 1,14 & 0,13 & & & $\mathbf{0 , 7 2}$ & Normal-log \\
\hline 14 & Solok Air Santok & 33 & $\mathbf{0}$ & 0,84 & 1,14 & 0,15 & & & 0,89 & Normal-log \\
\hline 15 & Simpang Alai & 39 & $\mathbf{0}$ & 1,29 & 1,14 & 0,33 & 3,47 & 3,47 & 3,47 & Gama-III dan LP-III \\
\hline 16 & Danau diatas & 31 & $\mathbf{0}$ & 0,99 & 1,14 & 0,20 & 1,47 & 1,47 & 1,47 & Gama-III dan LP-III \\
\hline 17 & Pasel Surantih & 30 & $\mathbf{0}$ & 0,92 & 1,14 & 0,18 & $\mathbf{0 , 5 1}$ & 0,51 & $\mathbf{0 , 5 1}$ & Gama-III dan LP-III \\
\hline 18 & Pasel Tarusan & 36 & $\mathbf{0}$ & 1,30 & 1,14 & 0,34 & 2,03 & 2,03 & 2,03 & Gama-III dan L.P-III \\
\hline 19 & Sijunjung & 31 & $\mathbf{0}$ & 0,99 & 1,14 & 0,21 & & & 1,12 & Gumbel \\
\hline 20 & Solok Sumani & 30 & $\mathbf{0}$ & 0,22 & 1,14 & 0,01 & & & $-1,08$ & Normal \\
\hline 21 & Muaro labuh & 40 & $\mathbf{0}$ & 1,27 & 1,14 & 0,32 & & & 1,06 & Gumbel \\
\hline 22 & Padang Gunung Nago & 34 & $\mathbf{0}$ & 2,93 & 1,14 & 1,29 & & & 2,98 & Normal-log \\
\hline 23 & Pdg Pariaman Talang & 32 & $\mathbf{0}$ & 0,90 & 1,14 & $\mathbf{0 , 1 7}$ & 0,73 & 0,73 & $\mathbf{0 , 7 3}$ & Gama-III dan LP-III \\
\hline 24 & Paskar Ujung gading & 30 & $\mathbf{0}$ & 0,58 & 1,14 & 0,07 & 2,06 & 2,06 & 2,06 & Gama-III dan LP-III \\
\hline
\end{tabular}


Tabel. 11 Rekapitulasi jenisdistribusi deret data debit annual exceedances dari Provinsi Sumatera Barat berdasarkan uji parametrik

\begin{tabular}{|c|c|c|c|c|c|c|c|c|c|c|}
\hline \multirow{2}{*}{ No } & \multirow{2}{*}{ Nama Stasiun } & \multirow{2}{*}{$\begin{array}{r}\text { Jumlah } \\
\text { Data }\end{array}$} & \multicolumn{6}{|c|}{$C_{\text {ssyarat }}$} & \multirow{2}{*}{$C_{s}$} & \multirow{2}{*}{ Jenis Distribusi } \\
\hline & & & $\mathbf{N}$ & N-L & G & G-II & G-III & LP-III & & \\
\hline 1 & Sungai ipuh & 35 & 0 & 2,11 & 1,14 & 0,78 & & & 1,16 & Gumbel \\
\hline 2 & Tanah datar Buo & 31 & 0 & 0,86 & 1,14 & 0,16 & & & 1,18 & Normal- Log \\
\hline 3 & 50 Koto tj Pati & 34 & 0 & 2,75 & 1,14 & 1,18 & & & 1,05 & Gumbel \\
\hline 4 & 50 Koto Suliki & 30 & $\mathbf{0}$ & 1,53 & 1,14 & 0,45 & 1,82 & 1,82 & 1,82 & Gama-III dan LP-III \\
\hline 5 & Agam Gumarang & 28 & $\mathbf{0}$ & 2,50 & 1,14 & 1,01 & 2,86 & 2,86 & 2,86 & Gama-III dan LP-III \\
\hline 6 & Agam Maninjau & 30 & $\mathbf{0}$ & 1,81 & 1,14 & 0,60 & 0,42 & 0,42 & 0,42 & Gama-III dan LP-III \\
\hline 7 & Batu Busuk & 38 & $\mathbf{0}$ & 2,91 & 1,14 & 1,28 & & & 1,05 & Gumbel \\
\hline 8 & Koto Tuo & 40 & $\mathbf{0}$ & 1,99 & 1,14 & 0,70 & 0,31 & 0,31 & $\mathbf{0 , 3 1}$ & Gama-III dan LP-III \\
\hline 9 & Mangopoh & 27 & $\mathbf{0}$ & 2,29 & 1,14 & 0,88 & 2,53 & 2,53 & 2,53 & Gama-III dan LP-III \\
\hline 10 & Padang Panjang & 35 & $\mathbf{0}$ & 1,94 & 1,14 & 0,68 & 1,44 & 1,44 & 1,44 & Gama-III dan LP-III \\
\hline 11 & Pariaman Kandang IV & 32 & $\mathbf{0}$ & 1,65 & 1,14 & 0,51 & & & $-0,02$ & Normal \\
\hline 12 & Pariaman Lubuk Napar & 32 & $\mathbf{0}$ & 1,81 & 1,14 & 0,60 & 1,99 & 1,99 & 1,99 & Gama-III dan LP-III \\
\hline 13 & Pariaman Kasang btg anai & 30 & $\mathbf{0}$ & 1,73 & 1,14 & 0,56 & 0,89 & 0,89 & 0,89 & Gama-III dan LP-III \\
\hline 14 & Solok Air Santok & 33 & $\mathbf{0}$ & 1,70 & 1,14 & 0,54 & & & $\mathbf{1 , 1 0}$ & Gumbel \\
\hline 15 & Simpang Alai & 39 & $\mathbf{0}$ & 2,17 & 1,14 & 0,81 & 2,60 & 2,60 & 2,60 & Gama-III dan LP-III \\
\hline 16 & Danau diatas & 31 & $\mathbf{0}$ & 1,70 & 1,14 & 0,54 & 1,40 & 1,40 & 1,40 & Gama-III dan LP-III \\
\hline 17 & Pasel Surantih & 30 & $\mathbf{0}$ & 1,81 & 1,14 & 0,60 & 0,91 & 0,91 & 0,91 & Gama-III dan LP-III \\
\hline 18 & Pasel Tarusan & 36 & $\mathbf{0}$ & 1,80 & 1,14 & 0,60 & 2,46 & 2,46 & 2,46 & Gama-III dan LP-III \\
\hline 19 & Sijunjung & 31 & $\mathbf{0}$ & 2,18 & 1,14 & 0,82 & & & 1,08 & Gumbel \\
\hline 20 & Solok Sumani & 30 & $\mathbf{0}$ & 1,11 & 1,14 & 0,25 & 0,41 & 0,41 & $-0,41$ & Gama-III dan LP-III \\
\hline 21 & Muaro labuh & 40 & $\mathbf{0}$ & 1,67 & 1,14 & 0,52 & & & 1,77 & Normal-log \\
\hline 22 & Padang Gunung Nago & 34 & $\mathbf{0}$ & 5,76 & 1,14 & 3,17 & 2,68 & 2,68 & 2,68 & Gama-III dan LP-III \\
\hline 23 & Pdg Pariaman Talang & 32 & $\mathbf{0}$ & 1,65 & 1,14 & 0,51 & 0,89 & 0,89 & 0,89 & Gama-III dan LP-III \\
\hline 24 & Pasbar Ujung gading & 30 & $\mathbf{0}$ & 0,74 & 1,14 & 0,12 & 1,80 & 1,80 & 1,80 & Gama-III dan LP-III \\
\hline
\end{tabular}

\section{SIMPULAN}

Dari 24 (dua puluh empat) deret data debit annual maxima dan annual exceedances di Propinsi Sumatera Barat tidak ada distribusi yang representatif di setiap pengujian karena itu harus di lakukan perhitungan dan pengamatan sendiri disetiap stasiun penakar hujan.

\section{UCAPAN TERIMA KASIH}

Kepada Seluruh Dosen, Staf Pengajar, dan Karyawan/ti Fakultas Teknik, Jurusan Teknik Sipil atas bantuan yang tidak pernah lelah.membagikan ilmunya selama saya mengajar di Universitas Muhammadiyah Sumatera Barat

Kepada Dinas Pengelolaan Sumber daya Air Provinsi Sumatera Barat dan khususnya Saudara Namunc Sukmara atas bantuan dan dukungannya sehingga terselesainya Jurnal rangteknik ini.

\section{DAFTAR PUSTAKA}

Agus, I., 2010, Penentuan Jenis Distribusi dan Uji Kesesuaian Smirnov Kolmogorov Data Hujan DAS Taratak Timbulun Kabupaten Pesisir Selatan, Rekayasa Sipil, halaman 42-51.

http://ojs.polinpdg.ac.id/index.php/JRS/arti cle/view/221 (diakses pada tanggal 26 Juni 2014).

Agus, I., Hartati, 2011, Uji Kesesuaian Chikuadrat Data Hujan DAS Batang Kuranji Kota Padang, Rekayasa Sipil, halaman 99-111.

http://journal.polinpdg.ac.id/index.php?opti on $=$ com content $\&$ view $=$ article $\& i d=9 \& I$ temid=1\&article_id=240 (diakses pada tanggal 26 Juni 2014).

Anderson, T. W., D. A. Darling 1954, A Test of Gooness of Fit, Journal of the American Statistical Association, Vol. 49, No. 268 halaman 765-769.

http://links.jstor.org/sici?sici=0162-

$1459 \% 28195412 \% 2949 \% 3 \mathrm{~A} 268 \% 3-$ 
C765\%3AATOGOF\%3E2.0.CO\%3B2$\underline{\mathrm{L}}$ (diakses pada tanggal 15 Juli 2014).

Bedient, P. B., dan Huber W. C. 1992, Hydrology and Floodplain Analysis, Addison-Wesley Publishing Company, $712 p$.

Frank, J., Massey, Jr., 1951, The Kolmogorov-Smirnov test for goodness of fit, Journal of the American Statistical Association, Vol 46, No. 253, Pages $68-78$ http://www.jstor.org/discover/10.2307/2 280095?uid $=2129 \&$ uid $=2 \&$ uid $=70 \&$ uid $=4 \&$ sid $=21104671643393 \quad($ diakses 10 sept 2014)

Harto, S., Br., 1993, Analisis Hidrologi, Penerbit PT. Gramedia Pustaka Utama, Jakarta, 303p.

Haan, C. T. 1979, Statistical Methods in Hydrology, The Lowa University Press.

Machairiyah, 2007, Analisis Curah Hujan Untuk Pendugaan Debit Puncak Dengan Metode Rasional Pada DAS Percut Kabupaten Deli Serdang, Tugas Akhir S1, Universitas Sumatera Utara, Medan.

http://www.researchgate.net/publication/42 349045 Analisis Curah Hujan Untuk Pendugaan_Debit_Puncak_Dengan_Met ode_Rasional_Pada_Das_Percut_Kabup aten_Deli_Serdang (diakses pada tanggal 26 Juni 2014)

Mera, M., 2011, Hidrologi Rekayasa, Penerbit CV. Ferila Padang, 179p.

NIST/SEMATECH，2014, Engineering Statistics Handbook, http://www.itl.nist.gov/div898/handbook I (diakses 07 Oktober 2014)

PSDA, 2009, Publikasi Data Hujan Tahun 2000-2010, Dinas Pengelolaan Sumber Daya Air Provinsi Sumatera Barat, Padang.

PSDA, 2010, Publikasi Data Hujan Tahun 2012-2013, Dinas Pengelolaan Sumber Daya Air Provinsi Sumatera Barat, Padang.

PSDA, 2011, Publikasi Data Hujani Tahun 2014-2015 Dinas Pengelolaan Sumber Daya Air Provinsi Sumatera Barat, Padang.

Rodrik, T., K. S. Lubis, Supriadi, 2013 , Kajian Distribusi Curah Hujan Pada Beberapa Stasiun Penakar Curah Hujan di DAS Padang, Jurnal Online Agroekoteknologi, halaman 373-379.

http://jurnal.usu.ac.id/index.php/agroekotek nologi/article/view/5838 (diakses pada tanggal 18 Juni 2014).

Ruhiat, Y., 2013, Distribusi Curah Hujan Harian dengan Uji Chi-square, Kolmogorov-Smirnov, dan Anderson Darling (Studi Kasus: Distribusi Curah Hujan Stasiun Serang), Prosiding Seminar Nasional Matematika dan Pendidikan Matematika 2013, Universitas Andalas Padang, halaman 133-139.

Scholz, F. W., M. A. Stephens, 1987, KSample Anderson-Darling Test, Journal of the American Statistical Association, Vol. 82, No. 399, pages 918-924.

http://links.jstor.org/sici?sici=0162-

$1459 \% 28198709 \% 2982 \% 3$ A399\%

3C918\%3AKAT\%3E2.0.CO\%3B2-

9(diakses pada tanggal 15 Juli 2014).

Stephens, M., A., 1974, EDF Statistics for Goodness of Fit and Some Comparisons, Journal of the American Statistical Association, Vol. 69, No. 347, pages 730-737.

http://www.tandfonline.com/doi/abs/10.108 0/01621459.1974.10480196\#.U_wq-

$\underline{\mathrm{KOKqM}}$ (diakses pada tanggal 15 Juli 2014).

Stephens, M., A., 1992, An appreciation of Kolmogorov's 1993 Paper, Technical Report No. 453, Dept. of Statistics Stanford Univ., 22p.

https://statistics.stanford.edu/sites/default/fi les/SOL\%20ONR\%20453.pdf (diakses pada tanggal 07 Oktober 2014).

Sudjana, 2005, Metoda Statistika, Penerbit Tarsito, Bandung, 508p.

Sutikno, dan A. Bey, 2003, Analisis Peluang Untuk Memprediksi Kejadian Iklim Ekstrim "Studi Kasus: Distribusi Curah Hujan di Kabupaten Karawang, Indramayu dan Subang”, J. Agromet, halaman 62-72.

http://journal.ipb.ac.id/index.php/agromet/a rticle/view/3592 (diakses pada tanggal 18 Juni 2014).

Usman, H., P. S. Akbar, 2011, Pengantar Statistika, Penerbit PT. Bumi Aksara, Edisi Kedua, Jakarta, 363p. 
Widyasari, T., 2009, Kurva Intensitas

Durasi Frekuensi (IDF) Persamaan

Mononobe di Kabupaten Sleman, Janateknika, halaman 85-94.

http://jurnalteknik.janabadra.ac.id/wp.../Bu _titik_09.pdf (diakses pada tanggal 5 Juli 2014). 